\title{
Pinguicula vulgaris in southern Saskatchewan
}

by Gweneth J. Jones, University of Saskatchewan, Regina

On May 28, 1964, during a botany field trip in the Strawberry Lakes region we discovered an abundant stand of Pinguicula vulgaris, the Common Butterwort. The plants were first noticed by Dr. G. F. Ledingham who had previously seen the species
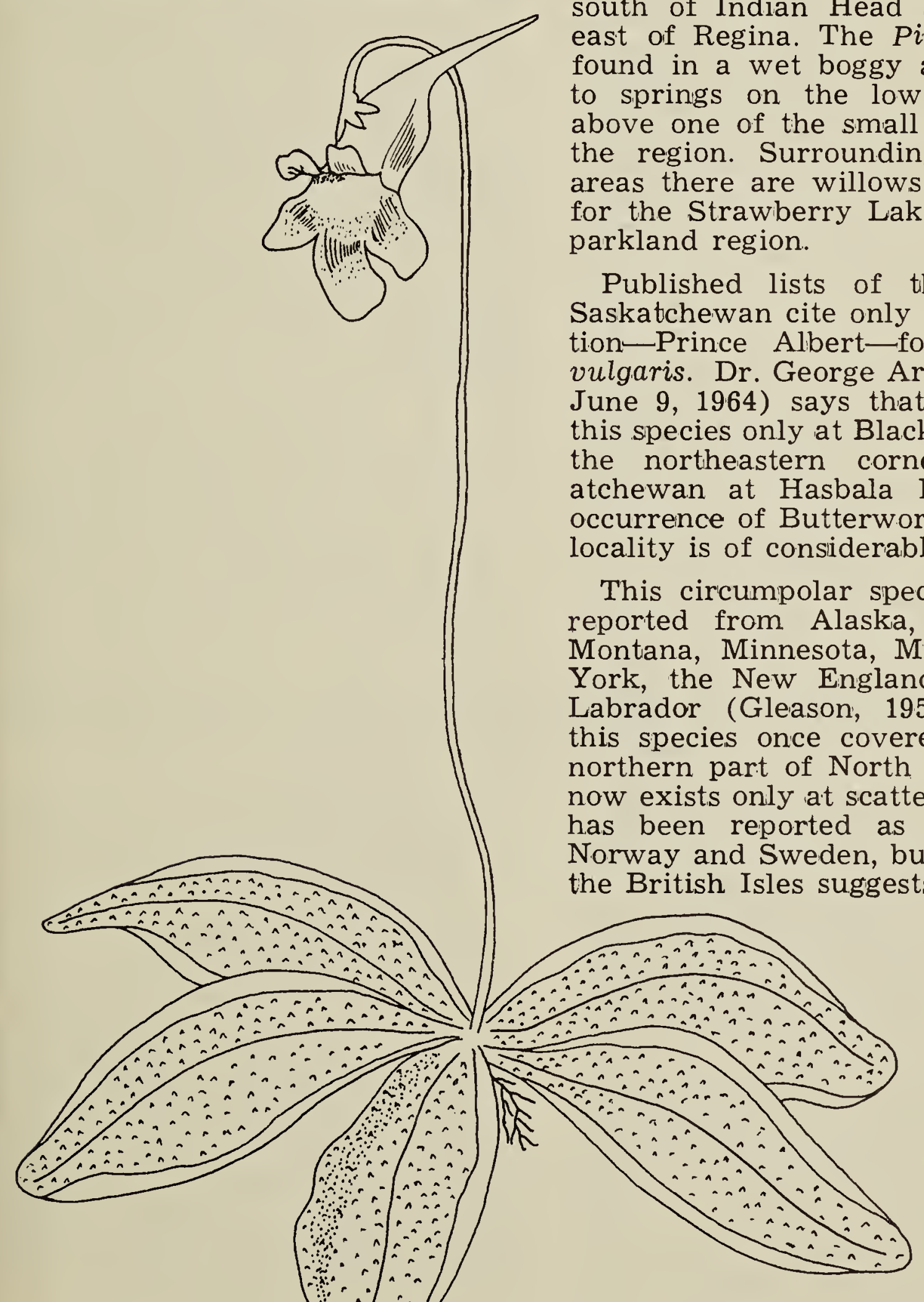

Sketch by Gweneth Jones in peat bogs at Prince Albert. Misses Lynda Roney and Janice Zacharias, research assistants at the University in Regina, were also present when the plants were found.

The Strawberry Lakes occur in a rather sandy area about 10 miles south of Indian Head and 42 miles east of Regina. The Pinguicula was found in a wet boggy area adjacent to springs on the low open banks above one of the small dry lakes of the region. Surrounding the boggy areas there are willows and poplars, for the Strawberry Lakes are in the parkland region.

Published lists of the plants of Saskatchewan cite only the one location-Prince Albert-for Pinguicula vulgaris. Dr. George Argus (letter of June 9,1964 ) says that he has seen this species only at Black Lake and in the northeastern corner of Saskatchewan at Hasbala Lake; so the occurrence of Butterwort at this new locality is of considerable interest.

This circumpolar species has been reported from Alaska, Washington, Montana, Minnesota, Michigan, New York, the New England States and Labrador (Gleason, 1952). Possibly this species once covered all of the northern part of North America and now exists only at scattered points. It has been reported as abundiant in Norway and Sweden, but a survey of the British Isles suggests that it may 
have disappeared since no specimens have been found in recent years. $P$. vulgaris is a northern species, and as such it might be expected to disappear in the course of a gradual climatic amelioration. It was, therefore, very exciting to find this species existing in southern Saskatchewan where it has probably survived for some 10,000 years and now may be considered a post-glacial relict.

Pinguicula vulgaris is a small plant found in wet meadows and bogs. It may appear similar to a violet because the corolla is a rich purple color and is two-lipped, the upper lip with two parts and the lower lip with three lobes. The ccrolla lobes are delicately veined and the lower lobes are covered with white hairs. The corolla terminates in a long straight spur. The flowers appear in May to July on erect stalks or scapes (5-15 $\mathrm{cm}$. tall) growing from the center of a basal rosette of 3 to 7 yellowishgreen leaves.

The basal leaves are broadly oval or elliptic and obtuse. Each leaf may be slightly hollowed like a trough, with the upper surface covered by many hair-like stalked glands. The tip of each gland is moist with a sticky substance which is fatal to any small insect alighting on the leaf. The contact of the insect's body stim- ulates the glands to secrete extra mucilagincus material causing the insect to become permanently trapped in this "living fly paper".

Sometimes the leaf margin curls over the victim thus aiding in its capture. The body of the insect is acted upon by an acid digestive juice and the soluble nitrogenous material is absorbed by the leaf. Not only insects but pollen grains and bits of vegetable matter falling on the leaf are also absorbed. The digestive action of the Butterwort leaf has been used for centuries by the Laplanders in making a junket-like food out of milk which has been poured over the leaves (Hylander, 1944).

The viscid or greasy appearance of the leaves is responsible for the name Pinguicula, derived from the Latin adjective "pinguis" meaning "somewhat fat" (Fernald, 1950).

It would be interesting to know if this plant occurs in other localities, and we would like to correspond with readers who may know of its occurrence.

\section{LITERATURE CITED}

Fernald, M. L. 1950. Gray's manual of botany. American Book Co., New York.

Gleason, H. A. 1952. Britton and Brown illustrated flora of northeastern United States and adjacent Canada. Vol. 3. Lancaster Press, Lancaster, Penn.

Hylander, C. J. 1944. The world of plant life Macmillan Co., New York.

\section{Corrections on Butterfly Determinations by Ronald Hooper, Punnichy}

My brother Donald and I have had articles in the Blue Jay describing some of the species of butterflies in our collection. After sending most of our collection away and having it checked by professional lepidopterists, we find that we had made some errors in determinations which we should like to correct.

In the Blue Jay of March, 1953, my brother mentioned some of the butterflies we had taken at Scmme, Saskatchewan. Here are the corrections that should be made for the species mentioned in that article:

Chariclea Fritillary should read Purple Lesser Fritillary

Afra Blue should read Silvery Blue

Clouded Sulphur should be deleted

Western Sulphur should read Giant Sulphur
Pale Swallowtail should read Tiger Swallowtail

Northern Dusky-wing should read Northern Cloudy-wing

Sleepy Dusky-wing should read Dreamy Dusky-wing

Accius Skipper should be deleted

In the Blue Jay for September, 1960 , we mentioned some of the species of butterflies that we caught in the Cypress Hills. The following species should be deleted: Chalcedon Checkerspot, Baird's Swallowtail, Creus Marble, Palaeno Sulphur, Nastes Sulphur, Juvenal's Dusky wing, Acmon Blue.

In the future, when we repcrt on butterflies collected, we shall name only those species determined by experts. 